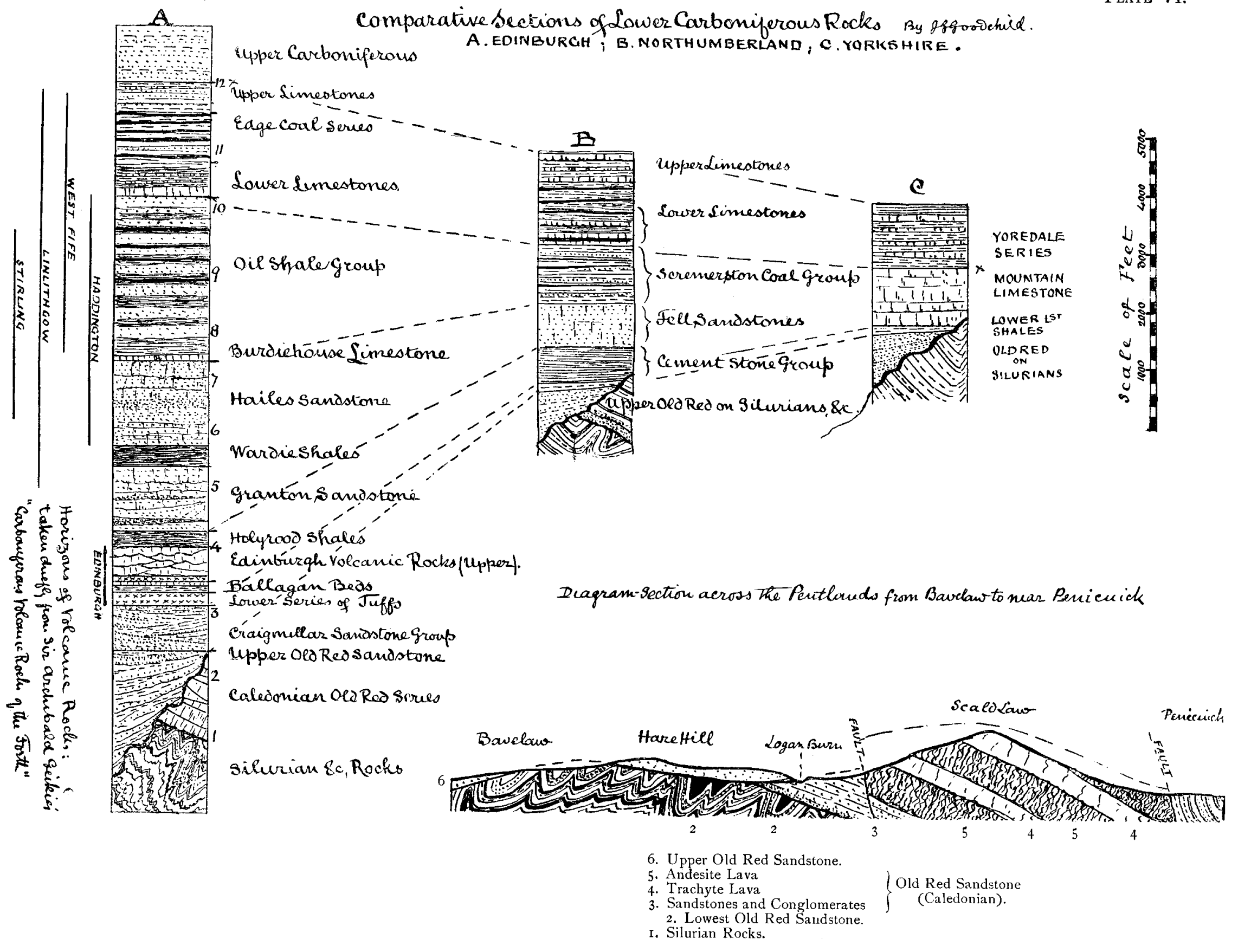




\title{
AN OUTLINE OF THE GEOLOGICAL HISTORY OF THE ROCKS AROUND EDINBURGH.
}

\author{
By J. G. GOODCHILD, H.M. Geol. Survey, F.G.S., F.Z.S., M.B.O.U., Curator of the \\ Collection of Scottish Geology and Mineralogy in the Edinburgh Museum of Science \\ and Art.
}

[Read July 2nd, 1897. Communicated by permission of the Director-Gereral of the Geological Survey.]

\section{INTRODUCTION.}

THE geological structure of the district of which Edinburgh is the centre is so complex, and the evidence available for its study is of so disconnected a character, that it is hardly possible, even with the aid of good maps and guides, to study all its essential features in less time than twenty whole days. One may, it is true, visit and carefully examine part of the field evidence in less time than that; but to attempt to gain any real insight into the geological structure of the district as a whole in less time than that named would be to leave unseen much evidence of a kind that cannot well be gathered from either maps or books. Without a proper understanding of much of this evidence in the field, the geologist simply has to take on trust from others, statements which it is of much, importance that he should test on the ground for himself, if his visit is to be of real use.

In writing the outline which follows, I have borne this difficulty constantly in mind, and have endeavoured to plan such a course of excursions as may, when completed, form a consecutive series, which will enable the geologist who studies the evidence on the ground, with the Geological Survey Maps in hand, to gain a comprehensive view of at least the broader features of each locality visited, and to pass from the consideration of the oldest part of the geological record extant around Edinburgh step by step to that of successively-later chapters of its history as far as the commencement of Upper Carboniferous times. In the concluding note some features of interest in connection with the later records of the district have received attention. To fill in any of the larger details within these outlines the Geologists' Association will need to come again.

I have accordingly arranged to study ( 1 ) in the Pentuand AREA, the Lower or Caledonian Old Red Volcanic Rocks, and their relation to the Silurian rocks below and to the Carboniferous AUGust, I 897.? 
rocks above; then (2) at Copeth* (SICCAR POINT), the relation of the Upper Old Red Sandstone to the rocks older in the series (here the Gala terrene of the Silurians); next (3) to study the older part of the Lower Carboniferous strata and their associated volcanic rocks in and around ARTHUR's SEAT; then (4) to take up the history of the Lower Carboniferous rocks at Burntisland and carry it on by studying the fine sections exposed between KINGORN and KIRKCALDY, until we arrive within sight of the base of the Upper Carboniferous rocks at the town last named.

Beyond that, part of the later history will be taken up by Professor Geikie at ST. Monans and Eile.

Finally we shall study (5) some further part of the later history of the district by the aid of what can be seen at the Brackford and Braid Hirls.

Owing to tides, and other circumstances, these excursions caunot well be arranged in the consecutive order here given; but this will not materially affect the general plan.

The Comparative Table of I.ower Carboniferous Rocks (Pl. VI) appended to this will serve to explain much referred to in the text.

\section{I.-Pentland Excursion.}

Leaving the Caledonian Station by train for Balerno, we enter upon the part of the Lower Carboniferous rocks in which are situated the Sandstones of Hailes, Redhall, and Craigleith, and their associated shales of Wardie, etc., and we continue along their strike nearly the whole distance. The route lies most of the way amongst the picturesque scenery of the Water of Leith. On our right as we go lie strata which, on the whole, are somewhat higher in the Lower Carboniferous series; on our left successivelylower beds, also of Lower Carboniferous age, tise with the dip, or are faulted up to the surface, so that lower and older beds form the rising ground in that direction. With the uprise of the Carboniferous strata the base is eventually brought to the surface, and there emerges from beneath that base the massif of older rocks which once formed the floor upon which the Carboniferous rocks lay, but which, owing to its having been bent into an anticlinal fold from which the Carboniferous rocks have been subsequently denuded, is now left as the hard core of that anticlinal, which has been carved by rain and rivers into picturesque moun-

* Generally spelled "Cockburnspath" ; the termination peth occurs in Morpeth, Elspeth, Brancepeth : in Pethhead, Peth o' Condy, and others. It is said to be Celtic, and to mean "a grassy fiat at the foot of a steep bank."

Postscript.- Since the foregoing notes were written Sir Archibald Geikie's Ancient Volcanoes of Great Britain has appeared. I have not yet had time to read it through, but I have already seen enough of it to warrant me in warmly recommending its study to all those who really desire to understand this most fascinating branch of geology; and especially to those who wish to learn all that is known regarding the volcanic rocks around Edinburgh.J. G. G., May 2oth, I897. 
tains and valleys. In brief, this may be regarded as the history of the Pentlands as a mountain-chain.

With the history of the Carboniferous rocks there, we have on this occasion but little concern; it will suffice to repeat that, as we ascend the slopes leading to the Pentlands from Balerno Station, we pass over the edges of successively-lower strata, until at Bavelaw Castle we come down upon the Upper Old Red, and, not much farther on, we meet with highly-inclined rocks of Silurian age, upon whose upturned edges the Upper Old Red here, as at the Siccar Point, lies with a violent unconlormity. The Silurian rocks referred to are part of the mass of highlyplicated greywackes and argillites of Wenlock to Ludlow age, whose denuded edges constitute the floor upon which the chief masses of the Pentlands were laid down. These have the S.E. strike which characterises all the Pre-Devonian rocks in the south of Scotland. In the quarries and the natural sections to be visited by the Association a few fossils are to be found by carefully searching the rocks. These organic remains are chiefly small mollusca and brachiopoda, with a few monoprionidian graptolites, such as Monograptus priodon, $M$. colonus, $M$. vomerinus, and Retiolites. The chief Pentland localities for fossils are, however, some distance off, and could not well be visited by the Association on the present occasion.

Upon the upturned ends of these Silurian rocks (and also in places upon the upturned ends of the sandstones which are generally classed with the Lower Old Red) lies, with a violent unconformity, the Old Red Series (Caledonian Old Red, mihi) of the Pentlands. Where these rocks are most fully developed they consist of a considerable thickness of basal conglomerates (very probably filling up old valleys, and representing the torrential débris of this part of the Devonian period here), which conglomerates are succeeded by fully 6,000 feet of lavas and tuffs, with some few bands of sandstone." The whole series was almost certainly laid down under continental conditions, while sub-arid meteorological conditions prevailed. Their relations to the overlying Upper Old Red, and to the Silurians as well as to both the Lower Old Red Sandstones, are shown diagrammatically on the plate of sections accompanying this.

The conglomerates, as might be expected to be the case under these circumstances, are of very local occurrence; so that in places they are entirely absent, and the lavas repose directly upon the floor formed by the edges of the Silurian Rocks. This is the case close to Bavelaw Castle. The conglomerates (here, as elsewhere) are full of interest, if only on account of their containing a most varied assortment of rocks derived from the Lower and Upper Silurian, etc., rocks of the Southern Uplands. They are seen in

- Sir Archibald Geikic (Ancient Volcanoes of Great Britain) gives a most valuable summary of what is known regarding the rocks of Devonian age of the Pentlands, etc. 
Logan Burn and Monksburn, and they include in these places many blocks of the Arenig Radiolarian Chert, now altered into jasper ; also blocks of the Haggis Rock, a conglomerate of Bala age; and a host of other rocks as well. In addition to these, this Pentland conglomerate has long been celebrated for containing blocks of a fossiliferous limestone, which has hitherto not been satisfactorily traced to its parent source. Mr. Peach thinks it may be one of the Silurian limestones, which locally occur at no great distance. Its fossils, however, appear to many persons to possess a different facies from those of the Silurian rocks.

During the building up of the volcanic rocks which now form the Pentlands, it must often have happened, especially towards the close of the period when the volcanoes had reached a great size, that the superincumbent pressure upon the molten rock rising in the direction of the surface was too great for the subterranean impelling agent to overcome. Under those circumstances, much of the rock that would have taken on the form of a lava flow, if it had risen to the surface, was forced in amongst the strata under ground. In some parts it would invade the Silurian rocks, in others the overlying conglomerates, and in yet other localities the lavas and tuffs. One such mass, of considerable size, and producing contact phenomena of considerable interest, will be passed on the way across the hills. This is the rock of Black Hill, which, by the way, may really be of the nature of a laccolite - that is to say, it may have been intruded under such conditions of temperature, fluidity of the mass, and superincumbent pressure, as to allow of the molten mass actually lifting the overlying strata, as laccolites are shown to do in text-books, and as intrusive masses are almost never found to do in the field. But there is no clear proof that it is so, even in this case.

The volcanic rocks consist chiefly of lavas, the tuffs being thin and relatively unimportant. The lavas, lithologically considered, are somewhat more varied than is usually the case. Generally the Old Red lavas consist of but little else than one or other of the many forms of Andesite; but these of the Pentlands range almost from basalts, or at least from basalt-andesites, through andesites of various kinds, to trachytes, or even more acid lavas than these. The lowest lavas are andesitic, then come more acid rocks, next a second andesite group, followed by a second more acid series, and terminated, so far as the present section is concerned, by andesite once again. A few necks, representing the cores of parasitic cones, occur here and there, but are not seen along the line between Balerno and Penicuik. It will be seen by the Survey Map that the rocks of the Braid Hills have been mapped as part of a great neck. Some of the tuffs show interesting examples of raindrops, which, in descending through an atmosphere charged with fine volcanic dust, have caught up much of this and have reached the earth as globules of ashy mud. 
Dr. Johnston Lavis appears to have been the first to recognise these. A good example is seen in a quarry between Scald Law and Carnethy.

After the volcano ceased to erupt, the whole area underwent some disturbance and considerable denudation, and then the Upper Old Red was eventually deposited, still under continental conditions, upon the very irregular surface formed by the older rocks. After that came a change of climate from arid to humid, perhaps as a consequence of the descent of the land. During this subsidence the Carboniferous rocks, twelve or more thousands of feet in thickness, were deposited over the entire area now occupied by the Pentlands.

Of its later history there is no need to state much here. Valleys were carved into the massif long prior to the Glacial Period. During that time land ice flowed from the mountains lying to the north-west of the Forth basin, thence up the Clyde, over the watershed of that river into the basin of the Forth, and then over all the hills of the Lowlands out to what is now the North Sea. The very highest summits, as well as the slopes, of the Pentlands, are marked with the characteristic grooves and striæ left by the ice; and the boulder-clay, which represents the mud and sediment carried upward and forward in the ice sheet, now forms the till, and is the source of the many far-derived boulders for which the Pentland area has long been famous. Some boulders of mica schist from near Loch Lomond lie close to the path from Balerno to Penicuik, and can easily be inspected. One of these near Loganlee has been much visited and often described. It weighs several tons.

One or two small moraines of the later glaciers occur in this neighbourhood; but the most striking example is to be found nearer the southern end of the Pentlands, in the neighbourhood of West Linton and Slipperfield, where a fine crescentic group of moraines of large size lies off the mouth of one of the larger valleys. I am not aware that its nature has been previously noticed.

Just before leaving the Pentlands properly so called, the party will have an excellent opportunity of obtaining good specimens of the so-called "porphyrite" of Carnethy, which is an andesite lava containing large tabular crystals of twinned labradorite. Agates occur in this, as does also mineral bitumen, together with small crystals of cairngorm.

The Pentlands are bounded on the east side by a large fault, which lets down the Lower Carboniferous rocks near to the hills. These dip towards the low ground at a high angle, and are stained by infiltration from the New Red rocks which have lately disappeared, so that Upper Carboniferous rocks, bright red in many cases, occur there to a considerable thickness, and were at one time regarded as Permian. 
Close to the boundary fault occurs a small group of eskers, which, as the present writer first suggested in $1874, *$ represent the stony materials which were liberated from the interior of the ice sheet on to its surface as it melted, and were afterwards washed down into the gradually-widening crevasses.

\section{II--Siccar Point and "Cockburnspath" or Copeth.}

On the arrival of the train at "Cockburnspath" (or Copeth, as it is locally and more commonly called), the party will walk along the road in the direction of Berwick. Part of the way the journey will lie over the sandstones at the base of the Lower Carboniferous Rocks, and then for a short distance over the Upper Old Red Sandstone. At Peaseburn a fine example of a dene eroded in these rocks will be examined. The Old Red here consists of the usual alternations of red sandstone and conglomerate, which dip in a northerly direction or, on the whole, down the burn. The dene is a typical example of a smaller valley, more or less in the form of a canon, lying within a larger valley whose sides slope at a much lower angle. Its history appears to be that the larger valley was shaped by sub-aerial causes by the ancestor of the present burn before the Glacial Period, when the land stood at a much higher level, and when what is now the North Sea was then simply the valley of the Rhine. During the Glacial Period the old valley was modified by glacial action, one of the results being the formation of a series of grooves of glacial origin, which, as Sir Archibald Geikie pointed out in the Geol. Survey Memoir on the Geology of the Berwick Coast, here furrow the surface of the rocks in a south-easterly direction. Near the close of the Glacial Period the land had subsided to considerably below its present level. On the disappearance of the ice, the water of the North Sea gained admittance to this part, perhaps for the first time, and some of the higher-lying marine terraces were formed, of which conspicuous examples do not happen to occur in this immediate neighbourhood. Under these conditions the flow of the Peaseburn at this point must have been reduced to its lowest possible rate, with, as a consequence, a minimum amount of vertical erosion compared with the lateral. Then the land rose in a succession of starts, with long pauses between each. At every uprise the rate of flow of the stream at a point close to the sea must necessarily have been increased in proportion to the gradient so formed, and the vertical eroding power of the burn was therefore increased in relation to the rate of lateral erosion. Patches of the old alluvium 
found when the land stood at a much lower level above the sea remain on the edges of some of these denes fifty or sixty feet above the present level of the stream.

Leaving Pease Bridge the party will next walk in the direction of the quarries at Old Cambus. Here the rocks consist of close alternations of beds of greywacke and argillite, this latter being occasionally affected by cleavage, and therefore becoming a slate. The rocks in question belong to the Gala Group, equivalent to the Welsh Tarannon subdivision of the Silurian, and the equivalent in time also of the Pale Slates of the English Lake District. As might be expected, considering their mineral composition, they are very much thicker than their deep-water equivalents in the Lake District. They have been subjected to intense compression, which has thrown them into a series of complex folds whose axes range in a general N.E. and S.W. direction. Professor Lapworth pointed out many years ago that it is rocks mainly of this age, repeated by innumerable closely-pressed and often inverted folds, which constitute fully one-third of the superficial area of the Scottish Southern Uplands. It is almost entirely out of these convoluted greywackes and argillites that the Lammermuirs and Moorfoot Hills have been shaped. It is these, also, which form the striking range of cliffs of greater part of the Berwickshire coast. Figures showing the remarkably convoluted character of these rocks are given in the Survey Memoir by Sir Archibald Geikie on Sheet 34, Scotland.

It can easily be shown that the disturbances to which these convolutions are due commenced at a period late in the history of the Silurian rocks themselves, and were continued, contemporaneously with denudation to a prodigious extent-many thousands of feet of rock having been removed in the processuntil the rocks were planed down to near the geological horizons out of which much of the present surface is shaped. Upon the upturned and denuded edges of these were afterwards laid down the great group of volcanic rocks whose remnants constitute the Cheviots, and many of the patches of eruptive rocks seen along the coast from a little north of Berwick to St. Abb's Head.

Long after volcanic action ceased arid or perhaps even desert conditions set in here, and it was under these conditions, while the land stood at a much higher level, that the Upper Old Red Sandstone was formed. This consists partly of torrential deposits, chiefly accumulated in old wadys, strata formed in inland lakes, and wind-blown sands. Then came a gradual change from arid to humid conditions, accompanying - and probably a consequence of-the long-continued subsidence under which the Carboniferous rocks were formed. After a long series of other changes the newer rocks were in their turn removed and the present surface features left. 
The party will spend about one hour at Old Cambus Quarry, where typical examples of the fossils characteristic of the Gala Group, or of rocks in general of Tarannon age, may be found. Here, on Easter Monday of I897, the present writer's students obtained ten species of graptolites. These were identified by Mr. Macconochie as : Monograptus priodon, $M$. pandus, $M$ : vomerinus, $M$. exiguus, $M$. turriculatus, $M$. convolutus, $M$. hisingeri, $M$. crispus, $M$. leptotheca, and Diplograptus sinuatus; together with many good examples of " annelid" tracks.

After leaving Old Cambus Quarry the party will traverse one of the remarkable south-easterly grooves above referred to as occurring so commonly along this part of Berwickshire. Like the easterly grooves of the Lothians, these Berwickshire grooves coincide in direction with the glacial markings, and with the general direction of transport of the far-travelled boulders. I do not hesitate to regard the furrows in question as the work of land ice during the Glacial Period, as was originally suggested thirty-four years ago by Sir Archibald Geikie.*

After a walk of a few hundred yards along the furrow just mentioned, the party will climb its eastern bank, and in the course of a few minutes' walk will find themselves at the edge of a cliff of thinly bedded bright-red sandstone. This is the Upper Old Red. It is somewhat disturbed and faulted. It yields scales of Holoptychius along one of the bands, which band, though easily seen, there will not be time to visit. Going northwards along the edge of the cliff about a hundred yards or so, we come upon a steep grassy bank leading down to the foot of the cliff. Taking due precautions in the descent, we soon find ourselves face to face with the celebrated unconformable junction of the Upper Old Red Conglomerate and the Silurian (Tarannon) rocks, first recognised by Hutton. 'These latter are almost exactly vertical, and strike at right angles to the coast, while the Old Red lies with a very gentle inclination upon the edges of the older rocks, and strikes in a general way nearly parallel to the coast. It will be observed that the plane of junction between the two formations is a somewhat uneven one, as indeed is usually the case with strata formed under continental conditions, especially when these coincide with an area of small rainfall. As other examples of strata so formed, the New Red and the Torridonians may be mentioned. The conglomerate is of course made up largely, though not exclusively, of the finer torrential matter transported from the areas of older palæozoic rocks. It contains in addition to these constituents some stones from the older Old Red which formerly corered these parts, and also some few others whose origin cannot be traced with certainty.

It may be of interest to reflect upon the time represented by

- Op. cit?, p. 52. 
GEOLOGICAL HISTORY OF ROCKS AROUND EDINBURGH. I25

this grand example of an unconformity. According to the computation made by the writer, the changes that took place after the formation of the Gala or Tarannon Rocks at the Siccar Point and before the commencement of the period when the Upper Old Red was formed, require for their accomplishment I $50,000,000$ years. *

Returning to the edge of the cliff, the party will walk northward along the strike of the Old Red for about a quarter of a mile, beyond which they will again descend to the beach, for the purpose of studying the petrographical characters of the Upper Old Red, of which rock at one point a considerable thickness will be traversed. The beds above the basement conglomerate consist of alternations of sandstones and flags, showing much strongly marked false-bedding, such as occurs in desert sandhills, together with beds of red marl, which probably represent deposits formed in the "schotts" of the period. Poikilitic mottling is remarkably well seen in many places. Much of the sandstone consists of well-rounded grains of quartz, etc., in no way distin guishable, except in colour, from the desert sands of Egypt of the present day. Much secondary quartz is deposited upon the faces of the cleaner of these grains, and very beautiful examples can easily be obtained.

After a rough scramble over the fallen blocks for a distance of a few hundred yards, we find ourselves, as we go northward, crossing the edges of sandstones and marls in which the ferric oxide colouration gradually disappears, and in which more or less calcareous concretionary masses begin to make their appearance in the sandstone. These evidently mark the incoming of more humid conditions and the gradual increase in organic matter swept into the waters. By degrees, as the succession is followed northward and upward, plant- and animal-remains begin to occur in the rocks, the sandstones no longer consist of rounded grains of sand and are no longer red or mottled, and we are at the base of the Carboniferous rocks.

If time permit, these Carboniferous rocks may be followed as far as Cove; otherwise the ascent will be made sooner.

\section{III.-AR'THUR'S SEAT.}

The earlier chapters of the geological histcry of Arthur's Seat bring before us a record of an old land surface, probably formed mainly of rocks belonging to the Caledonian Old Red, but partly also shaped out of the ends of highly contorted Silurian and other rocks of still older date. There is good reason for believing "Goodchild, "Age of the Earth," Proc. Royal Physical Socicty (1897), vol. xiii,
pp. 259-308. 
that the land surface in question was one presenting much irregularity of form; but whether any of the eminences formed of these older rocks which exist as elevated areas now were such then, is by no means certain in all cases. The Upper Old Red Sandstone which was deposited upon this surface certainly contains records of a period when arid conditions prevailed here; for whatever rain fell, came at intervals too irregular to permit of the growth of vegetation. Hence, where the form of the ground was such as to permit of the existence of lakes, the quantity of organic matter swept into those lakes was usually too small to reduce the iron salts carried in solution into them. Consequently these iron salts were usually left, coating the sand grains as ferric oxide.*

Under these arid conditions was formed a series of deposits which, in some places, were simply accumulations of wind-blown sands, in others torrential deposits filling up the old wadys, in yet others deposits formed in old "schotts," like those of Algeria. Hence the distribution of the Upper Old Red, here as elsewhere, is one of great irregularity; and there are necessarily many areas where no deposits of any kind belonging to this period were left.

Rocks formed in this way constitute the surface strata all over the southern part of Edinburgh.

Towards the close of the period subsidences of a local nature commenced, and were continued for some time. One important result of the change was the introduction of meteorological conditions of a different order from what had prevailed before. Rain fell with more regularity, the quantity of aqueous vapour in the atmosphere considerably reduced the diurnal range of temperature, and rock-weathering of the normal type again prevailed. With the return of humid conditions vegetation flourished, and animal life began to abound.

It was under these conditions that the rocks occurring in the northern part of the Old l'own of Edinburgh and the western parts of the Queen's Park were formed. The sea had not yet gained a permanent entry; but the area probably formed part of a lagoon, or consisted, perhaps, of a series of lagoons, liable to alternate flooding and desiccation; the rate of deposition of rock material brought in by the old river, whose course here lay south-eastward, being generally balanced by the rate of subsidence. During the periods of drought concentration of the salts brought down by the river went on, and we accordingly find temporary records of an occasional return to conditions similar to those under which the Upper Old Red was formed. Sun cracks, rain prints, shale galls, pseudomorphs of rock-salt, variegated sandstones and marls - here reddish, there green-are found alternately with sandstones and shales of the normal colour. But owing to the frequent presence of organic matter in the river water, ferric 
oxide was precipitated much less frequently than before. The same cause also gave rise to another effect of some interest and importance. 'The river brought down lime-salts in solution, probably sulphate of lime amongst the others. The joint action of desiccation and the presence of organic matter gave rise to the precipitation of much of this. Generally the precipitated carbonate of lime took the form of nodular concretions, or cornstones; but in many cases here it would seem to have been deposited in the form of thin crusts. These irregular sheets of chemically-formed carbonate of lime were generally broken up, and their fragments drifted seawards each time a flood came, and were thus mingled with the older derivative material being swept forward by the currents.

Under some such conditions as these were the rocks formed which now constitute the dip slopes on the west side of Hunter's Bog, and most of the steep scarp extending downward from Salisbury Crag to the Queen's Drive below; they are also well seen on the south-east side of the Edinburgh Castle Rock and at Craigmillar, from which locality they are named.

These strata exactly correspond in petrographical character and in stratigraphical position to the rocks called the L ower Limestone Shale on the English side of the Border.

Then followed a more rapid subsidence, during which the sea may frequently have gained admission, although the general absence of organic remains forbids us to speak with absolute confidence upon this point. Under these conditions was formed a mass of shales and cement stones, with occasional bands of sandstone, and some few bands of limestone of a peculiar type. The rocks referred to are the Ballagan Beds of Glasgow geologists. 'Ihey are probably the same as the Cement Stone Series of the Border counties and the lower part of the Roman Fell Series (and therefore of the Mountain Limestone) of Westmoreland, as is shown in the comparative sections appended to this.

While these rocks were in process of formation here a volcano, or, perhaps, a series of volcanoes, arose in some part of the area to the west of the area specially under notice. (Many geologists, looking westward from the present Arthur's Seat, have been led to speculate whether the Edinburgh Castle Rock might not mark the site of the volcano in question; but upon this point there is at present not much agreement amongst them.) The precise nature of its earliest eruptions must always remain unknown; but we do know that while the Ballagan Beds were being deposited in the area now represented by the Queen's Park and the Calton Hill the volcano did now and then, early in its developmental history, give rise to explosive eruptions, which occasionally were of a sufficiently violent nature to project more or less fragmentary eruptive material to such a distance as to fall within one part or another of the areas under notice. Hence 


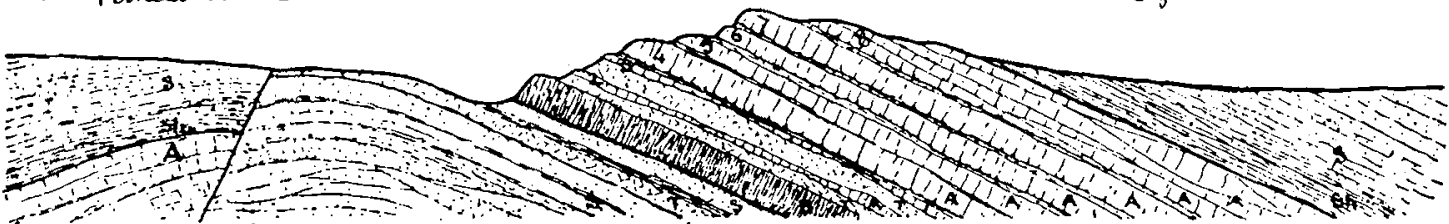

Wfincy-ticle

E.

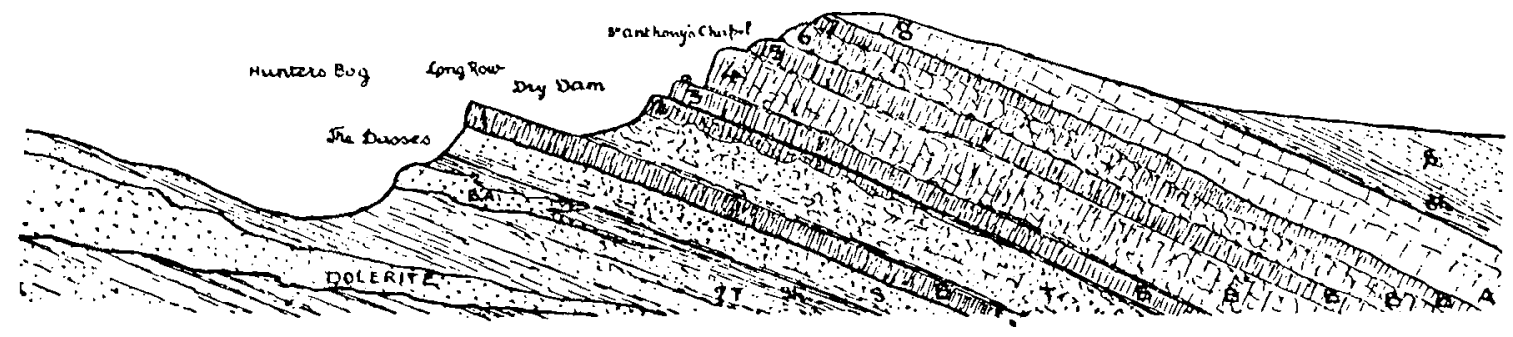

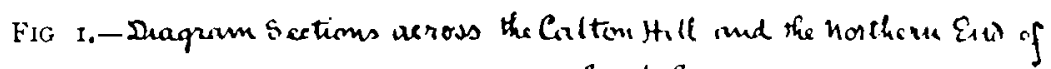

Onthars' Soat

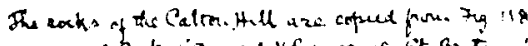

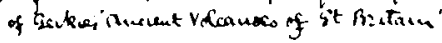


it happened that the Ballagan Shales came to be interstratified with bands of tuff. Rocks formed during this period now form the lower part of Hunter's Bog, and much of the rising ground to the east of that depression. They occur also along the High Strect and the Canongate of Edinburgh, and were lately passed through in the Abbey Hill Bore, No. 2, cores from which are exhibited in the Edinburgh Museum of Science and Art.

Concurrently with the upgrowth of the volcano there arose hot springs, and perhaps also geysers. From these were deposited beds of calcareous and siliceous sinter, which were spread out in thin layers in the vicinity of their orifices. During the earthquakes that accompanied the growth of the volcano these beds of sinter underwent many crumplings and occasional fractures, after each of which events quiet deposition went on as before. Several deposits of this kind occur in connection with the old Edinburgh Volcano, and may be seen at various places in the Queen's Park.

Then came a succession of periods of more violent explosive eruption, alternately with conditions favourable for the growth of beds of sandstone. This rock was seen at the Waverley Station, and below the IVaterloo Bridge, and was also passed through in the borehole No. 2 at $\Lambda$ bbey Hill, above referred to (see also Trans. Geol. Soc., Edin., I897, p. ).* These were followed by the outpouring of one or more beds of basalt lava, while the area was still submerged. One of these flowed in the direction of Arthur's Seat, and now forms the Long Row. Another may be represented by the lowest lava seen below the Calton Gaol. Then came a period of quiescence, during which another band of geyserite was formed. 'This is' seen on the south side of the Queen's Park, between Windy Gowl and the Qucen's Drive. A succession of explosive eruptions of a more or less violent character next took place. Then came a basalt lava flow, which was heavily charged with $\mathrm{H}_{2} \mathrm{O}$, and is in consequence now full of vapour cavities, some of which have been at one time filled with amygdules of calcite. This flowed in the direction of the Queen's Park only, as it is not represented on the Calton Hill.

Submergence still continued, and perhaps kept pace with the growth of the volcano, for we find that the beds overlying the last-mentioned lava consist of stratified tuff, in which remains of Rhizodus and transported fragments of Lepidodendron occur. In these beds, which are, as a rule, fine-grained, and of only a few feet in thickness, there occur large ejected blocks, one of which, seen just below St. Anthnoy's Chapel, may really be a volcanic bomb, which, it may be mentioned here, is a geological phenomenon of by no means common occurrence, notwithstanding what has often been stated to the contrary. This thin bed of tuff is succeeded on Arthur's Seat by a compact basalt

* This paper is not yet paged, September Irth, 1897 . 
lava, very columnar in structure, showing traces of fluxion structure on its weathered surface and weathering a bright rust-red colour. This is No. 3 Lava. No lava of basaltic composition occurs on the Calton Hill above the bed at the base of the series, the higher beds there being exclusively andesites. From this consideration, and others of a similar nature, we may infer that the present outcrop of the older lavas on Arthur's Seat does not coincide with the original longer dimensions of the lava streams, but rather with their breadth, those on the Calton Hill representing streams from other vents.

Another bed of geyserite, accompanied by a thin band of tuff, succeeds the red lava (No. 3), and is followed by a remarkably brecciated lava (No. 4). Probably the portion of the rock exposed, which is best seen in the cliff-face due east of St. Anthony's Chapel, may be near the original termination of this lava stream, which, as is well known in the case of recent lavas, is often both scoriaceous and brecciated in much the same manner as the one under notice.

Three other lava-flows poured from the Edinburgh Volcano in the direction of what is now the Queen's Park. Of these the older two were basalts, the lower of which even yet contains olivines in a fresh condition, and is remarkable for its bomboidal or pillowy structure. The higher lava, and last flow of this set to reach Arthur's Seat, is a true andesite, similar to those which form the mass of the Calton Hill volcanic rocks, and containing large tabular crystals of Labradorite. This is the rock which forms most of the eastern side of Arthur's Seat, and which both caps and forms the east slope of Dunsappie.

Contemporaneously with the eruption of these lavas and tuffs there was intruded underground three sheets or sills of rock. The lowest of these is a porphyritic basalt, which now forms the rock of St. Leonard's Crags and Heriot Mount. This rock occurs in the form of a wedge, with its base towards the west. It cuts across the strata from below upwards, as it is traced southward. The next is a typical dolerite, whose remains form a scarped edge, which presents a bold mural precipice facing to the westward, the well-known feature known as Salisbury Crags. Speaking in general terms, this rock also forms a wedge-shaped mass, thickest towards the west. It hardens the strata above it, but in the main it does not vary much from one geological horizon. Both of these may possibly represent underground intrusions of basic eruptive matter, which are possibly contemporaneous with the lavas of the same composition forming the main mass of the hill. 'The third intrusive mass is of a similar composition to that of the highest lava of the Queen's Park, and the bulk of the lavas of the Calton Hill, and is essentially an andesite. 'This rock forms a series of apparently discontinuous wedges, which are intruded into the Ballagan Beds on the east side of Hunter's Bog. It forms the 
hills known as the Dasses. To these three intrusive masses reference will have again to be made.

The changes which followed the outpouring of the last-formed of the lavas on Arthur's Seat are not difficult to describe. The newly-finished volcano sank more rapidly than heretofore, and the sea for a time gained admittance. At the bottom of this was laid down a series of beds of marine shale, enclosing fossils; and then followed either a rapid silting up of the sea bottom or else a slight movement in an upward direction. At any rate, it is clear that the next strata formed (the Granton Sandstones of the General Section) were estuarine in character, and were formed throughout in shallow water. Then follows a record of a succession of marine conditions, marking the periods of more rapid subsidence, and of estuarine conditions when the water was shallower, and the old delta of the river, which was transporting the material from the north-west, effected more or less advance seaward. It is important to remember that the strata from the Ballagan Beds, up to the horizon under description, are undoubtedly equivalent in time to the Mountain Limestone of the North of England.

Next, in this area, followed the conditions which gave rise to the formation of lagoons, alternating with estuarine conditions, under which in this neighbourhood the Oil Shale Series was formed. This series is contemporaneous with the Scremerston Coals of Northumberland. It was also the chief period of I ower Carboniferous volcanic agency in the areas adjoining Edinburgh. Then came the period during which a very general subsidence took place, and when the limestones of the Yoredale Series were spread out continuously over so large an area of North Britain. The lowest limestone of this, the Hurlet, Main, or Gilmerton Limestone, is probably contemporaneous with the Middle Limestone of Phillips's typical Yoredale Sections, with the Scar Iimestone of Cumberland, and with the Lamberton Limestone of the Berwickshire coast. It is as well to remind the reader that the limestone referred to overlies the Oil Shales, and their contemporaneous deposits the Scremerston Coals so important in Northumberland, and that it underlies the Edge Coal Series, also of Lower Carboniferous age, which are of so much importance in Fife and the Lothians.

Following the marine episode during which the Yoredale Rocks were formed, came the prolonged period of estuarinepossibly even, occasionally, fresh-water-conditions, under which much of the Upper Carboniferous rocks were formed. It will suffice here to state that the older volcanic rocks of Arthur's Seat were covered up by several thousand feet of Carboniferous strata, all of which has, of course, since been removed by denudation.

Then came a period of prolonged disturbance, during which 
the first formed strata were much folded and faulted. This was followed by upheaval and denudation, and a return to continental conditions. It was under these conditions that the New Red Rocks (Dyas, Lower New Red, or Permian, plus the Trias) were formed. Sir Archibald Geikie described many years ago an interesting series of volcanic rocks which were formed in Ayrshire during this period, to which reference will again be made.

We must now, however, return to study some of the evidence relating to the later formed rocks on Arthur's Seat. The main facts may be set before the reader in a few words. It is abundantly clear from a study of the evidence on the ground that there are eruptive rocks belonging to tzoo periods on Arthur's Seat. The rock of the Dasses, for example, and the rock of the Long Row, can both be followed southward without any interruption up to a certain point, where they both abruptly terminate against rocks of a totally different kind, which are easily seen to be those of which Arthur's Seat, properly so called, consists. If we go to the south side of the hill, and commence the examination at the west end of Duddingstone Loch, we find there also the rock of the Dasses and the rock of the Long Row. Both of these can casily be traced northward up to a certain distance, and at that point what are very obviously agglomerates filling an old volcanic neck truncate them abruptly, just as happens on the north side of the hill. (It seems, even to the writer, that facts of much the same nature can be made out with regard to both the dolerite of Salisbury Crags and the basalt of Heriot Mount.) No unprejudiced geologist could well have any doubt about the fact that he has before him in this case evidence of two sets of eruptions. Of the age of the one, whose products have already been described, there can be no doubt whatever. But regarding the age of the other-that which broke through the older set of lavas, etc., and filled the gap so formed by agglomerates and other such material - there has been considerable difference of opinion. Some have thought the newer rocks might be of 'Tertiary age. Others have thought that the whole set may be of Lower Carboniferous age, and may have come from the vent now represented by Arthur's Seat. Sir Archibald Geikie has maintained for many years the view that the newer vent may be of Permian age-a view which finds many supporters in Scotland. The evidence bearing upon this question is certainly very scanty, and, as Sir Archibald himself states, in his latest work, The Ancient Volcanoes of Great Britain, cannot be settled by exclusive reference to the facts presented by the hill itself, but must be studied in the light obtained from sources elsewhere.

Leaving this vexed question, we may now pass on to consider some of the later history of Arthur's Seat.

Soon after the close of the Carboniferous Period, the newlyformed rocks were thrown into a great and complex series of 
elongated domes or ellipsoids, most of whose larger axes range in a general north-easterly direction, and whose steepest sides often face towards the east.

The axis of one of the great north-easterly upfolds coincided with the present physical axis of the Pentlands, which hills represent the harder core of one of the anticlinals re-exposed by the denudation of the softer strata which once folded over it. The axis of one of the main synclinals ranges parallel to this latter, and has helped to preserve the outlier of Upper Carboniferous forming the Dalkeith Coalfield from denudation. But so far as Arthur's Seat is concerned, we need only to have regard to the fact that the Pentland axis bends to the north as it ranges near Edinburgh, and then gives rise to a minor ellipsoidal area of upfolding, which traverses the site of Edinburgh along a northerly line ranging, in a general way, from the summits of the Braid and Blackford Hilis to near to the Castle Rock, and thence onward in the direction of Leith Docks. To the east of this axis the strata, including those of Arthur's Seat and the Calton Hill, were made to dip north easterly; while in the opposite direction they were inclined for some distance in a north-westerly direction. Arthur's Seat and the Calton Hill, it has to be remembered, once formed part of the east flank of the Edinburgh Volcano, of which they must be regarded as a segment accidentally preserved from the denudation which has removed most of the remainder, and were alike thrown, so to speak, on their side, when the strata of which they form a part underwent the north-easterly tilt referred to.

Then, some time after this folding took place, and while the old volcano still remained intact amidst its enveloping strata, a series of faults originated. These took a prevailing north-easterly direction. One very powerful one runs from Craiglockhart, along the west side of southern Edinburgh, to a point between the Castle Rock and Princes Street Station, and from there along the west side of the Calton Hill in the direction of Leith. This has thrown down a large section of the Edinburgh Volcano, which is accordingly beneath the surface of Princes Street. Another powerful fault, with a down-throw to the north, ranges between Holyrood and Arthur's Seat. Its effect, combined with that of the dip, has been to shift the outcrop of the Calton Hill section of the lava a mile to the west, and to bring down against strata three hundred or more feet below the base of the volcanic series, other marine strata which, on the Calton Hill and in both the Abbey Hill bore-holes, overlie the volcanic rocks. As the total thickness of these volcanic rocks has lately (1897) been proved, in the Abbey Hill bore-hole No. 2, to be 850 feet, ${ }^{*}$ the throw of this fault cannot be less than a thousand feet, and may considerably exceed that amount. Another segment of the Edinburgh Volcano,

* In the Abbey Hill bore-hole two sets of volcanic rocks were proved, with a considerable thickness of sandstone and shales (part of the Ballagan Beds) between them.

AUGUST, I 897.$]$ 
consisting of basalts of a different type from those on Arthur's Seat, is left at Craiglockhart. These are described in detail in the Ancient Volcanoes of Great Britain.

There is some reason to believe that the present surface relief of the neighbourhood of Edinburgh is a "modified descendant" of that which the surface had at the commencement of "l'ermian" times, and which has been re-exposed by the removal of these and the overlying rocks of Neozoic age. The characteristic red-staining of the sandstones which happened to contain but little carbonaceous matter, and which have formerly been overlain by Red Rocks, is well seen at many places around Edinburgh, and, to my mind, puts this point beyond doubt.

As far as the shaping of the minor details of the surface is concerned, we have three factors to bear in mind. First, the result of prolonged exposure of rocks of very diverse powers of resistance to atmospheric waste, factors which in any case must have operated in such a fashion as to leave Arthur's Seat, the Calton Hill, the Castle Rock, and the Pentland Hills as upstanding masses. The minor work of sculpturing must have been largely ruled by the variations in destructibility of what we may term a lower grade; as, for example, the formation of terraces where sills of hard rock, such as lava, alternate with others consisting of tuff. The second factor is, of course, that of the streams, which may and do excavate their channels without always having their courses affected by the minor differences referred to.

The third factor is that arising from the prolonged glaciation, which not only very materially modified any pre-existing features it may have met with, but left marks peculiarly its own upon the rocks. The conjoined effects arising from these may be easily traced upon Arthur's Seat, and it is not difficult to point out which feature is due to the one cause and which to the other. The best place for the study of them as a whole, however, is at the north end of the Pentlands, between Allermuir and Swanston. At this locality there is first the great upstanding mass of the Pentlands, due to the removal of the outer and softer coatings of an old anticlinal, whose less easily-wasted core has in consequence been left in relief as an area of uplands. Next are easily seen the channels eroded on the slopes of this old core by the streams whose courses had been well established in the strata that have since wasted away. Following these features in the order of magnitude are the escarpments and dip slopes arising from the inter-bedding of the lavas and tuffs, to which features Sir Archibald Geikie has so often made reference. Of lesser magnitude still is a series of deep grooves and ruts, which have been ploughed out of the edges of the escarpments by the passage over them of thick masses of land ice. Some of these grooves are of considerable magnitude; indeed on the Braid Hills, they would generally be 
taken for river valleys but for their obvious parallelism, and for the fact that they tend to run into chains of rock basins. Lastly, and of least importance, are the roughenings of the once smooth and rounded crags, and the consequent formation of screes. Anyone whose eye has fully taken in the special characteristics of these severai features, which are so well exhibited on the Pentland Hills, will have no difficulty in referring each grade of the surfacefeatures on Arthur's Seat to the agency to which it was actually due. The beautiful corrie at the head of Dry Dam, and the numerous small rock basins which have been carved out of the lavas of Whinny Hill (Samson's Grave, for example), will be at once recognised by the trained eye as the work of ice. As for the fine examples of roches moutonnées and other glaciated surfaces, they will tell their own story, save only to those who obstinately turn a deaf ear to any such appeals to their reason.

Several minerals of interest occur in the hill. Not counting the rock-forming minerals we have: Quartz, and its amethystine modification, Chalcedony, Jasper, $\Lambda$ gate, Chert in the geyserites, various forms of Calcite and of Pearlspar, Analcime, Prehnite, Natrolite, Celedonite, Glauconite, Hamatite, Limonite, Gothite, Barytes, some Hydrocarbons (probably due to chemical changes affecting metallic carbides occurring in the neck, as I venture to think the Dramondalso is), together with some few minerals of minor importance. Very fresh olivines occur in the older volcanic set, as well, of course, in the newer beds, such as that of the wellknown Lion's Haunch.

\section{IV.-Burntisland, Kingorn, and Kirkcaldy.}

The rocks exposed along this part of the Firth of Forth continue the history of the Lower Carboniferous rocks from the geological horizon described in the section dealing with Arthur's Seat, and carry it on through the period represented by the Yoredale Rocks, properly so called, well into the lower part of the Upper Carboniferous.

As already mentioned, the Carboniferous rocks of the lower part of the Basin of the Forth were affected by powerful earthmovements at some period between the close of Carboniferous times and the commencement of the period represented by the New Red. Extensive denudation accompanied and followed these disturbances, so that the New Red and the succeeding Jurassic rocks were spread out upon an uneven floor, shaped out of a vast thickness of the older strata. One ellipsoidal area of upheaval has already been mentioned as ranging in at first a north-easterly direction through the Pentland, the Braid, and Blackford Hills; thence, in its trend northward, it passes through 
Edinburgh and crosses the Forth, assuming, as it does so, first a north-westerly direction, and then bending round again to the north east, especially where the axis of the fold extends inland from Burntisland. Northward of this last town the fold gradually dies away. A synclinal, with a trend parallel to this, brings in, and has preserved from denudation, the Dalkeith Coalfield. This same down-fold crosses the Forth to the east of Inchkeith, and reaches the Fife coast to the east of Kirkcaldy, beyond which town this disturbance also gradually dies away.

At Burntisland (or a point a little to the west), therefore, we meet with the lowest strata exposed in this part of Fife; and from the axis passing through the part referred to the rocks are inclined with a fairly steady dip, amounting generally to about from ten degrees to twenty towards the east. In consequence of this high inclination of the strata, a thickness of Carboniferous rocks, amounting to several thousand feet, is brought down to the sea level within a zone a few miles in width. It happens in this area that the rocks are well-exposed in one part or another over nearly the whole of the coast, as well as in many fine sections inland. For this reason (and others to be presently mentioned) this part of the Fife coast has long been regarded as presenting one of the most important and instructive sections of the Carboniferous rocks to be seen anywhere in the British Isles.

The oldest rocks seen here represent the upper part of the great series of estuarine deposits referred to previously under the name of the Granton and Hailes Sandstone Group. 'These most likely correspond in age with the Fell Sandstones of Northumberland, and they are certainly of the same age as the Roman Fell Beds of W'estmoreland, and are also coeval with the lower part of the Mountain Limestone of North-west Yorkshire. At the time these strata were in process of formation the Fdinburgh Volcano had already ceased to erupt, and, as subsidence proceeded, was buried beneath a pile of newer strata of Lower Carboniferous age. The sea deepened towards the south-east, while in the opposite direction, at a distance as yet unknown, lay the old land. Oscillations of level were taking place, occasionally sufficient in downward extent to admit the sea ; but more usually the rate of subsidence did not quite keep pace with that of deposition, so that changes of current frequently took place, and during the growth and advance of the delta large areas were frequently converted either into lagoons or else were for a time laid dry.

In consequence a considerable variety of petrographical characters may be observed in these rocks. Amongst these are some curious bands of strata contemporaneously brecciated, which remind one of the "Broken Beds" of the Portland Oolite. The two other features of special interest are the Calcareous bands which represent the Burdiehouse Limestone and the Oil Shales. Of this latter type of rock one band has been worked for commercial pur- 
poses close to the Binn of Burntisland. Oil Shale consists essentially of shale which is more or less saturated with bituminoid matter capable under distillation of yielding paraffine and other hydrocarbons. The rock may be known by its somewhat leathery aspect, by its slight flexibility, and by its giving a more or less shiny streak when it is cut. This kind of rock has probably originated through the partial dissolution of the compound forming the vascular tissues of plants, which, while undergoing maceration in a lagoon, have been acted upon by water containing sulphate of lime in solution.* "The Burdiehouse Limestone consists essentially of carbonate of lime both mingled and interstratified with fine laminæ of the same material which forms the Oil Shales.

Soon after the Burdiehouse Limestone was formed, and evidently while the land was slowly subsiding, a volcano broke out on the site which is now occupied by the Binn of Burntisland. It may be remarked here that it must not be supposed from this that the Binn, which bears no small resemblance to an actual volcano, in any way represents the volcano itself. This hill may be said to bear the same relation to the volcano in question that the bole of a tree does to its branches. It is merely a neck, exposed by the denudation of the overlying strata and left in relief because it consists of material of a more durable nature than that of the strata surrounding it. It was certainly from this and some smaller vents around, some of which are well seen nearer Kingorn, that a pile of lavas and tuffs of basic composition, and of a collective thickness amounting to nearly as much as two thousand feet, was emitted.

The general nature of the eruptive material is exhibited in a remarkably fine manner along the coast extending from Burntisland, past Pettycur Point and Kingorn, to about half way from this latter place to Kirkcaldy.

A detailed account of this coast section will be found in Sir Archibald Geikie's Ancient Volcanoes of Great Britain, vol. i, p. 440, and again at p. 470 . In the present outline it will suffice to state that the coast section in question presents us with a remarkably fine and admirably-exposed series of basic lavas with their tuffs, alternating in their lower and earlier formed part with lagoon-formed strata of the age of the Oil Shales; and in their higher and later-formed portion, with sandstones, shales, and coal seams, of estuarine and marine origin, and with bands of pure grey marine limestone belonging to the horizon of the lower part of the Yoredale Rocks. Thus a band of encrinital limestone containing Productus giganteus (a fossil which is confined to the zones near the base of the Yoredale Rocks) may be seen in association with the basalt lavas and tuffs which emanated from the old volcano of the Binn.

\footnotetext{
* See Trass. Geol. Soc. Edin., I897, "Origin of Oil Shales."
} 
The finest continuous exposure of the lavas is to be scen on the face of King Alexander's Crag near Pettycur.

Amongst the fossiliferous beds occurring interstratified with the lavas and tuffs, and beneath the first grey limestone on the shore east of Kingorn, there is one stratum known as the Abden Bone Bed, beds associated with which have yielded us the following specimens of invertebrata :

Naticopsis variata, Bellerophon decussatus, Sanguinolites abdenensis, Edmondia unioniformis, Solenomya primava, Myalma gregaria, Myalina mytiloides, Aviculopecten ornatus, Pteronites persulcatus; Streptorhynchus crenistria, Productus semireticulatus, $P$. mesolobus; Rhabdomeson rhombiferum, Synoclodia biserialis.

For the list of Fish represented in the Abden Bone Bed sce Dr. 'Traquair's Note appended to this.

From a higher bed of shale, immediately underlying the second grey limestone on the shore north-east of Kingorn, the equivalent of the Hurlet Limestone (Yoredale), my students working with me have at one time or another found also the following species:

Orthoceras cylindraceum, Bellerophon decussatus, Euomphalus carbonarius, Pleurotomaria yvanii, Loxonema rugiferum, Naticopsis variata, Macrocheilus acutus : Nucula tumida, $N$. attenuata, Leptodomus sp. Schizodus like salteri; Productus semireticulatus, Spirifera trigonalis, Rhynchonella pleurodon, Athyris ambigua, Orthis michelini, Streptorhynchus crenistria, Lingula squamiformis, L. mytiloides, Discina nitida; Rhabdomeson rhombiferum, Synocladia biserialis; Lithostrotion junceum, Zaphrentis sp., Chotetes tumidus, Archaocidaris urei, Poteriocrinus crassus, etc.

Amongst the intrusive rocks formed probably in connection with this volcano are several sheets of dolerite, well seen around Burntisland and near Kirkcaldy. One excellent example of Picrite is seen at Colinswell, where the existence of this lithological type of eruptive rock does not appear to have been recognised until the writer called official attention to its occurrence there. It is remarkable (like the Picrite at Barnton) for its pseudobedded structure, which in both cases is probably due partly to mineral separation and partly to movement during consolidation; and is likewise noteworthy, as in the case just described, for its fine exemplification of the "chilled edge" it shows against the rock into which it is intruded, as well as for the discharge of colour which has ensued in all cases where a basic eruptive rock has been intruded into strata containing much carbonaceous matter. The Iserine found in the normal rock has given place near the contact to other forms of iron, which, through the action of the carbonaceous reducing agent, have passed from the form of a dense dark colouring ore of iron to one which possesses little or no colouring power, and, therefore, leaves the strata in the condition of "white trap." 
A very fine and instructive example of the same nature is to be seen at Iodhead Quarry, east of the Binn, where a basic intrude, which cuts across the stratification of some carbonaceous rock, has had its iron reduced while the rock was in a molten state, and has consequently assumed an appearance so much like that of sandstone that, in the old days of the rival Neptunists and Plutonists, it used to be cited as an example of a rock of sedimentary origin which was actually intruded as such into its present position.

Amongst the minerals occuring in this part may be mentioned Analcime, of which good crystals may sometimes be obtained close to the Abden Shipyard at Kingorn, Natrolite, Saponite, Celedonite, Amethystine Quartz, Pearlspar, Gœthite, and a few others. Hydrocarbons occur in connection with several of the neck rocks.

\section{V.-'The Braid and Blackford Hills.}

No outline of the geological history of Edinburgh would be complete that did not include some reference to the modifications of the surface features connected with the later changes of climate and elevation. In some respects the best general idea of these features can be obtained by visiting the Braid and Blackford Hills, whence also may be had the finest of the many fine views of the "grey metropolis of the north." "These hills form the northward termination of the Pentlands. In internal structure they consist of eruptive rocks of Lower Old Red Sandstone age. Their physical structure has already been referred to incidentally as arising from their having been the core of an anticline affecting Carboniferous rocks, from which core those Carboniferous rocks, more easily wasted than the underlying core, have been removed by denudation, leaving the upridged portion of their original floor in the shape of a semi-ellipsoidal mass. Concurrently with the removal of the Carboniferous rocks (some i 2,000 feet in thickness) from the summit of the dome, the Braid Burn (or its ancestral stream) has gradually worked down to its present level, ${ }^{*}$ thereby severing the dome into two massifs of smaller size-the Blackford Hill and the Braids.

The northern massif (the Blackford Hill) consists of a pile of andesite lavas, with thin partings of tuff, which are inclined at about fifteen degrees towards the north-east. 'The lavas naturally tend to form escarpments which face in the opposite direction. This feature can be well seen at the west end of Blackford Hill

\footnotetext{
- The Braid Burn presents one of the most instructive instances known (not even excepting the rivers draining northward from the Weald) of a small stream of feeble eroding power, preferring to cut its way across what nust al one time have been a continuous ridge of very hard rock, instead of taking what is now the ensier course seaward, and flowing past Colint on House into the Water of Ieith. At the point nentioned the watershed between the former levels of the 1wo streams is now not more than about ten feet in height.
} 
where seen from Morningside Road Station, and, in a less striking manner, where the Blackford Hill is viewed from the south, as from the Braids. From both points of view the trend of these escarpments forms a considerable angle with the course of the Braid Burn.

The Braid Burn had excavated this channel into something like its present form prior to the Glacial Period, as is proved by the occurrence of glacial strix at the bottom of the valley, and also by the occurrence, within the valley, of a thick mass of glacial drift containing far-travelled boulders. Near the climax of the Glacial Period the great ice-sheet slowly moved over this part in a general east-north-easterly direction (i.e., nearly parallel to the course of the Braid Burn, and in a direction forming a considerable angle with the outcrop of the lavas), and continued to move in that direction for a period of considerable length, if one may judge by the magnitude of the resulting effects. It is certain that the erosion accomplished by the prolonged movement of a sheet of ice which (seeing that it has glaciated the very highest ridges of the Pentlands) could not have been less, and may well have been much more, than two thousand feet in thickness, and whose lower portions were densely charged with stones, grit, and mud, very considerably modified the surface-configuration which resulted from subaerial erosion in pre-glacial times.

Subaerial erosion would almost certainly give rise to nearlycontinuous escarpments, in the cases like the present, where lava streams were based upon the more-easily wasted tuffs; and the cross section of each escarpment formed under such subaerial conditions would be rounded at its upper part into the form of an hyperbola. Glacial erosion considerably modified all that. Instead of continuous escarpments, those formed by the lava streams at the Blackford Hill are traversed by wide and deep furrows of a size sufficiently great to be almost entitled to be termed valleys. Instead of escarpments whose cross section formed a double curve, convex at the top edge of the lava, glacial erosion actually undercut the crags in many cases, leaving eventually a feature quite unlike any that could possibly arise from any form of erosion by subaerial causes.

If we commence the study of the Blackford Hill by viewing it first from the Braids this combination of features soon begins to impress us, and the longer the features are studied the more apparent does it become that we are regarding the work of ice superimposed upon features of subaerial origin. If, now, we change our point of view and take our stand upon the Blackford Hill and thence study the Braids in the same manner, features of the same kind, but on even a more striking scale, begin at once to attract our attention. The features referred to consist of a series of great east-and-west grooves of considerable magnitude, large enough in some cases to be entitled to be termed valleys. 
These grooves have attracted considerable attention from geologists since the earlier part of the present century. Sir James Hall,* Hay Cunningham, Robt. Chambers, Charles Maclaren, Dr. Buckland, Sir Roderick Murchison, Louis Agassiz, and others, have all noticed them, and have speculated much upon their origin. If such features were confined to this neighbourhood, and to these particular rocks, we might get over the difficulty about their origin by attempting to explain it as being in some way connected with the nature of the rock out of which they are carved, as, in fact, Murchison actually did do. But a glance at the adjacent Craiglockhart Hills, which are totally different both in structure and in age, shows us that similar features exist also there. Moreover, the whole north-west face of the Pentlands is grooved and furrowed in much the same way. So, too, is the dolerite mass of Stirling Castle; so also is Binney Crag in Linlithgow. Again we meet with the same features on Arthur's Seat, and on the Calton Hill. Many years ago Sir Archibald Geikie pointed out surface features of the same kind on the Garleton Hills in Haddingtonshire, and called attention to similar grooves traversing the maritime parts of Berwickshire and East Lothian.

Sir Archibald appears to have been the first to speculate whether ice may not have been the agent to which the Berwickshire grooves are due. It is absolutely impossible to explain them in any other way than by the eroding agency of a thick mass of ice charged with detritus and slowly grinding its way over the rock surface throughout a period of considerable length. It will be seen in every case that the directions of the longer axes of these great furrows coincide more or less closely with the directions of movement of the ice in the same district, as shown by the trend of the glacial striæ. Cumulative evidence of this kind, especially when further strengthened by a considerable body of collateral evidence, cannot fail to lead any unprejudiced geologist to the conclusion that the furrows in question are, like the smaller grooves which accompany them, simply the work of ice. I have gone further even that this, and have ascribed the great grooves which flank the ridge upon which stand the High Street, the Lawn Market, and the Castle Hill, of Edinburgh, as features which are due also to glacial action and to little or nothing else. $\uparrow$

If now we return to the Braid Hills and examine the grooves on the ground, we shall be at once struck by the fact that here, as in so many other cases (Samson's Grave, on Arthur's Seat, for example), these grooves do not present a uniform seaward gradient along their " thalwegs," but, on the contrary, they locally descend considerably below, and beyond that rise above that general

* See Murchison's Address to the Geological Society of London, 1842, pages 57, 58 .

† See Goodchild, "Glacial Furrows," Glacialists' Magazine, 1895. 
pradient. In other words, these grooves consist here, as in so many other localities, of chains of rock-basins connected by intervening depressions. How such features are to be explained by any other than by glacial action, I leave to others to answer who have wider field-experience than I have. There can be no question about ice having been in them, for good glacial stria exist in them at several places on the Braid.

Connected with this part of the subject is the remarkably-fine glaciated surface exposed close to the Braid Burn, on the south side of Blackford Hill, between the two great quarries there, and right and left of the quarrymen's tool-house. This is the glaciated surface which, when visited by Agassiz on the soth of October, 1840, * in company with Charles Maclaren, was at once recognised by Agassiz as being the work of land-ice. The foundations of our modern beliefs in such matters were therefore laid, so to speak, at this very spot.

A study of this remarkably-glaciated surface will do much to convince almost anyone that it is, and can be nothing else than, the work of land-ice. The rock-surface is considerably undercut, and, indeed, at one point the aspect of the glaciated surface is actually directed towards the centre of the earth; moreover, the striæ go in and out of all the minor depressions, and are not merely confined to the projecting parts of the surface.

Evidently what has happened has been that land-ice, originating in the Dumbarton, Perth, and Argyllshire mountains, has slowly worked its way up the Clyde Basin, over the water-shed into the Basin of the Forth, and then fowed across the Pentlands and along the Braid Burn for a considerable length of time. As the ice moved it eroded its channel more readily where it encountered a softer bed, such as a bed of tuff, and hence, in the long run, it undercut the escarpments of lava shaped by preglacial weathering. Then, when climatal conditions ameliorated, through the admission of the warm surface currents of the Atlantic into the North Sea area, in consequence of subsidence, the precipitation on the east of Scotland took the form of rain instead of snow. Under these climatal conditions the glaciers no longer grew, but began to melt away on the spot without making any further advance; and the stones and mud included within the ice were melted out as a kind of sediment, thereby giving rise to the various forms of glacial drifts. ${ }^{+}$This englacial drift filled the lower hundred feet or so of the valley of the Braid Burn, and its remains may be seen even yet on the south bank of the stream opposite the glaciated surface. Then the Braid Burn re-established its former course, and began cutting down through the boulder clay nearly to its

\footnotetext{
* Dr. Buckland soon afterwards described this Blackford Hill section in the same connection in a communication to the Geological Society of London.

tSee J. G. Goodchild "On Drift," Geol. Mag., I874, where the theory of the englacial origin of Drift Deposits was first published.
} 
old channel, keeping close to the north side of the valley in doing so, and thereby re-exposing the glaciated surface as the protecting cover of clay was removed. Traces of small alluvial deposits left by the Braid Burn, when flowing at higher levels, remain on the face of the rock even yet, and are among the many interesting things to be seen there. Since the close of the Glacial Period the weather has renewed its attacks upon the rock surfaces, and is slowly, but surely, restoring them to somcthing of the same aspect that they presented before the advent of glacial conditions.

A word must be added here, in conclusion, regarding the MINERALS to be obtained at the Blackford Hill Quarry. The decomposition of the andesite lavas where these are vesicular (which is not the case here) gives rise to complex products of secondary origin, such as celedonite, agates, natrolite, and other minerals. Here, however, these decomposition products are carried downward in solution through the body of the rock, only into joints and other divisional planes, along which they are subsequently re-deposited rather in the form of veins and strings than in the form of agates. Amongst these minerals so deposited may be mentioned fine examples of Quartz, including the amethystine form, Jasper, Carnelian, Chalcedony, Purple Chert, Pimelite ; fine dendrites of Manganese, (Gothite (rubinglimmer), Pearlspar,. Calcites of interesting crystalline forms, and various other minerals.

The gradual transition from the almost resinous form of the undecomposed andesite lavas (showing well-marked fluxionstructure) into the crumbling mass of rusty clay, which results from the decomposition of these lavas, is one of the most instructive features to be studied in the Blackford Hill Quarry.

\section{LIST OF THE FOSSII, FISH-REMAINS OCCURRING IN THE BONE BED AT ABDEN, NEAR KINGHORN, FIFESHIRE.}

BY R. H. TRAQUAIR, M.D., L.I.D., F.R.S., F.G.S.

[Read July $2 n d, 1897.1$

Eleven years ago, when Mr. William Anderson, now of the Geological Survey of India, submitted to me a collection of fishremains from the $A$ bden Bone Bed, I furnished him with a list which he inserted in a paper on the bed in question, which he read before the Geological Society of Edinburgh." $\mathrm{Mr}$. Anderson's paper was also accompanied by a short note by myself upon the bearing of the $A b d e n$ fossils on the question of the

\footnotetext{
* Notes on the Fish Remains from the Bone Bed at Alden, near Kinghorn. Proc. Geol. Soc., Edinl., vol. v, r886, pp. 320-314.

AUGUST, 1897.]
} 